\title{
The True North Urgency of the Earth in Determining the Direction of the Qibla According to Fiqh and Falak Science
}

\author{
Asmuni $^{1}$, Hasan Matsum ${ }^{2}$, Imamul Muttaqin ${ }^{3}$ \\ ${ }^{1,2,3}$ Islamic Law Study Program, Universitas Islam Negeri Sumatera Utara, Indonesia
}

\section{Abstract}

True North true north is any point on the earth to the North pole, this is because the North and South poles point precisely to the earth's axis of rotation. Therefore true north is North based on the earth's axis not North based on the earth's magnetism. So the difference is true North shows the true north direction of the earth while magnetic North is the North direction of the magnetic compass needle. Magnetic north does not coincide with Earth's true north. To find out the true North of the earth using a compass, you need to know the magnetic declination first. To know the magnetic declination can be done through a magnetic declination calculator such as WMM (world magnetic model) which can be downloaded through the crowdmag application playstore. In determining the direction of the Qibla it is required to determine the True North point of the earth.

\section{Keywords}

qibla direction; true north of earth; north of compass, declination of compass

\section{Introduction}

So far, the tool used to determine the qibla direction of mosques and musalla is a compass. In addition to determining the direction of the Qibla using a compass, it is very practical, this tool is also very easy to obtain. However, the total use of a compass in determining the Qibla direction can result in the wrong direction of the Qibla pointing to the Kaaba, this is because the North point shown by the compass is a magnetic North point. Meanwhile, in determining the direction of the Qibla it is required to determine the true North point of the earth. Using a compass should also be very careful because objects containing metals such as knives, watches, coins, etc. affect the compass needle so much that it does not show the true North of the Earth.

The most important thing and should be avoided using a compass in determining the Qibla direction is that the compass experiences magnetic declination, namely the deviation from the north direction of the compass needle's magnetic pole to the true north of the earth. The value of this magnetic variation is always different and changes at any time and place.

The Team for the Revision of the Revised Book of Hisab Rukyat explained that for the westernmost region of Indonesia, the westernmost region to the easternmost region, the magnitude of the magnetic declination lies between the price of approximately -1 degree to +6 degrees. The magnitude of the magnetic declination in a place can also be seen and determined from the magnetic declination map; generally this map is created or updated every 5 years, for example the Epoch 1990.0 map is valid for the period 1990-1995 onwards. The production and updating of these maps is in accordance with international regulations.

By ignoring the True North of the Earth in determining the direction of the Qibla, the direction of the mosque's Qibla tends to deviate and away from the Ka'bah. True North true north is any point on the earth to the North pole, this is because the North and South poles 
point precisely to the earth's axis of rotation. Therefore true north is North based on the earth's axis not North based on the earth's magnetism. So the difference is true North shows the true north direction of the earth while magnetic North is the North direction of the magnetic compass needle. Magnetic north does not coincide with Earth's true north. To find out the true North of the earth using a compass, you need to know the magnetic declination first. To know the magnetic declination can be done through a magnetic declination calculator such as WMM (world magnetic model) which can be downloaded through the crowdmag application playstore. Before that, the latitude and longitude of the mosque must be determined using a GPS (Global Position System) or coordinate map, or you can also download the Variation application,

Determining the direction of the Qibla by determining the True North of the Earth is very minimal and very urgent, especially if it is applied in calculating the Qibla direction in several mosques.

\section{Review of Literature}

Etymologically, according to Muhammad Rawas Qal'aji in Mu'jam Lughah al-

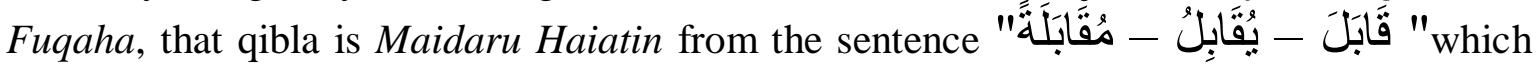
means :

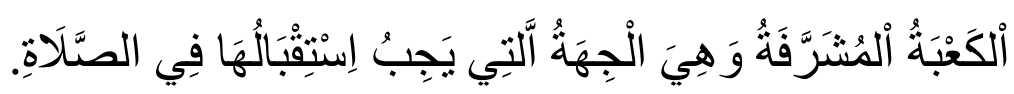

"The glorious Ka'bah is the jihat (direction) to which to pray ".

Meanwhile, according to Imam Nawawi in his Majmu :

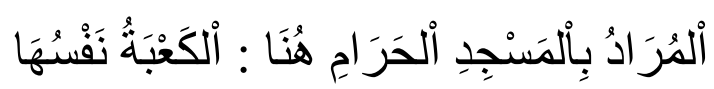

"The point is the Grand Mosque, namely: the building of the Ka'bah ".

The Qibla or Qibla is defined as the direction to the Ka'bah in Mecca (during prayer time), while in Latin it is called Azimuth. Based on the definition of the Qibla above, there are still mistakes in defining the Grand Mosque, Imam Nawawi said there are four kinds of definitions of the Grand Mosque, namely:

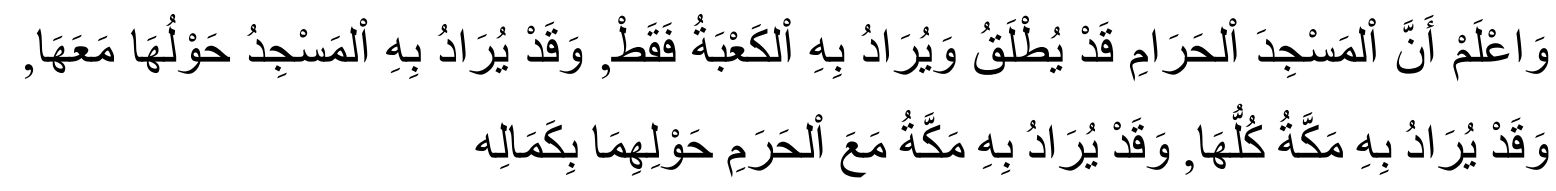

"That what is meant by the Grand Mosque is:

1. The Kaaba only.

2. Masjidil Haram and its surroundings.

3. The whole city of Mecca

4. The whole city of Mecca and all the Haram Land. "

Of the four definitions of the Grand Mosque above, Imam Nawawi stated the first opinion, namely, that what is meant by the Grand Mosque is the Ka'bah, as follows:

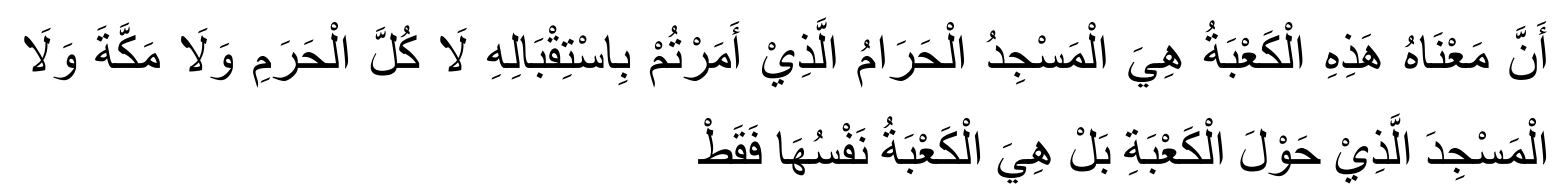


"That the meaning of this is the Ka'bah, namely the Grand Mosque which you are ordered to face is not haram land, Mecca is not also the mosque around the Ka'bah but what is meant is the Ka'bah itself".

The scholars agree that those who directly witness the Ka'bah must face the a'in ka'bah, namely the building of the Ka'bah which is shaped like a cube. Among the scholars who stated this was Ibnu Rusyd in Bid \pm yah al-Mujtahid:

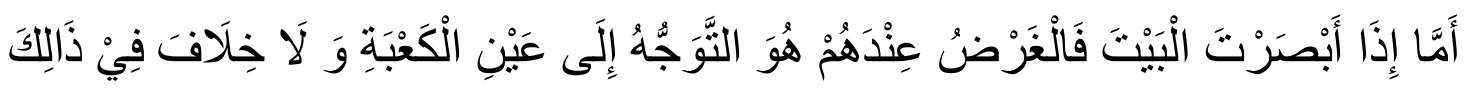

"If you can see the Baitullah (Ka'bah) directly according to them (the scholars) the goal is to face the Ka'bah there is no difference in this matter".

\section{Discussion}

\subsection{The True North Urgency of the Earth in Determining the Direction of the Qibla According to Fiqh}

North according to the language in Arabic is called الثَِّّمَالُ whereas in English it is called North, north in an essential sense is the point that intersects (limits) the meridian circle with the horizon in the northern part of the earth or sky. Whereas Earth's True north is the direction anywhere along the earth's surface towards the geographic north pole or true north pole ordirection from any point along the meridian towards the North Pole. North can be found with a compass, but the thing to note is that the compass does not show the true north of the earth but the direction of magnetic north.

The importance of knowing the true north of the earth in calculating the direction of the Qibla turns out to be in line with the jurists in fiqh literature, where according to the jurists in determining the direction of the Qibla for a place far from the Ka'bah one must know the true north of the earth. In terms of the objectives of syara 'or maqasid sharia, the goal of facing the Qibla by determining true north is part of hifzu al-din (maintaining religion) in the category of Hajjiyyat elements, namely maintaining religion or implementing religious provisions in order to avoid difficulties, such as facing the Qibla by determining north true of the earth, if this method is not done then it will not threaten the existence of that religion, it is just that it will experience difficulties in carrying out prayers. According to Muhajir, et al (2019) Prayers are the first worship required by Allah. Prayer has a great position in Islam and has its own position in Islam that is unmatched by any other position of worship.

As for the way of the jurists in determining the true north of the earth, it is not the same as now which uses many sophisticated modern tools, the jurists in determining the true north of the earth use the help of natural phenomena, namely by knowing the position of the polar star or in astronomy it is called a polaris star. As for some scholars who have this opinion, namely:

1. Ibnu Abidin from among the hanafi school

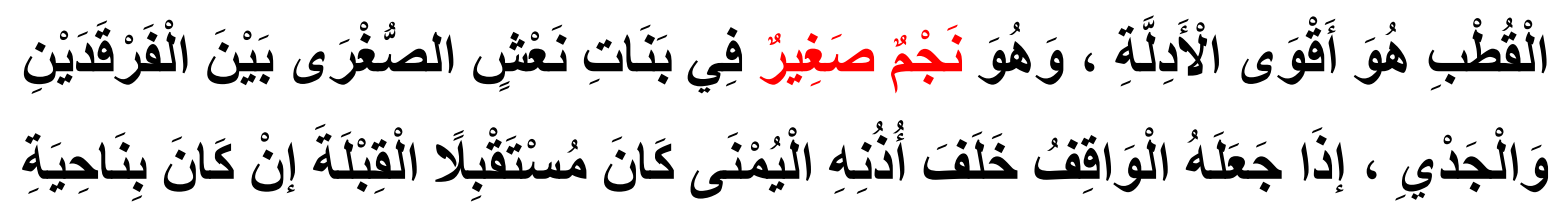




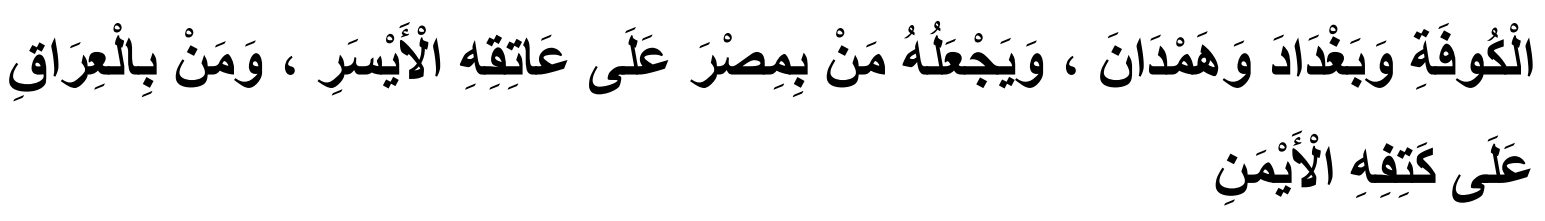

"The North Pole Star or Polaris is a small star that appears to be in one circle with the Ursa minor star located between 2 stars and the Jadyi star. If someone is in the Kufah, Baghdad and Hamdan regions, if he stands facing the Polaris star then the rear position His ear is facing the Qibla, for those in Egypt the direction of the Qibla is on his left shoulder when facing the Polaris star, for those who are in Iraq the Qibla direction is on the right shoulder".

2. Zakariya al-Ansari from among the syafi'i school

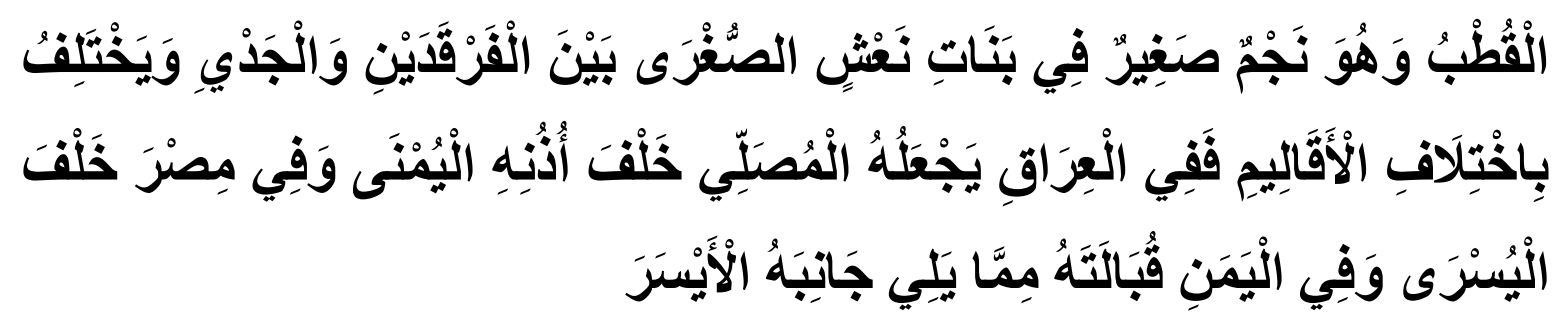

"The north polar star is a small constellation near the Ursa minor star, which is located between the perkad star and jaydi that position is different based on the climate of a region, in Iraq the polar star is behind the right ear of the praying person, in Egypt the polar star is behind the ear the left side of the person praying, while in Yemen it is in front of the person praying then tilt to the left".

At the time of the companions, tabi 'and tabi'in the polaris star was used to show them the true north direction of the earth. this is the determination of the true north of the earth, then through the help of this polaris star they can find out the direction of the Qibla in a very simple way through the limbs as previously explained, if someone already knows and faces this star, if he is in Egypt then the direction of the Qibla is in on the left ear so that when praying he turned his back on this polar star.Another way to find out the position of the Polaris star is by drawing the front line of the Usa major star towards the tip of the Usa minor star, so it can be a Polaris star and it is a pointer to the true north of the earth.

\subsection{The Urgency of Determining the True North of the Earth in the Calculation of the Accuracy of the Qibla Direction according to Falak Science}

To find out the true North of the earth using a compass, you need to know the magnetic declination first. To know the magnetic declination can be done through a magnetic declination calculator such as WMM (world magnetic model) which can be downloaded through the crowdmag application playstore. Before that, the latitude and longitude of the mosque must be determined using a GPS (Global Position System) or coordinate map, or you can also download the Variation application.

As an example of calculating the Qibla direction of the Muslim mosque Jl. H. Bahrum Jamil Kec. Medan City is known as Latitude 3.601898, longitude 98.708031. After that, activate the crowdmag program by entering the latitude of the place in the latitude and longitude column in the longitude column, after that make sure the positions of North (N) and East (E), then change the kilometer column to meters and fill in the altitude (altitude) of 50 meters. Please note that if crowdmag is used online, the date, month and year will automatically adjust, but if used offline, adjust the date, month and year with the measurement day of the Qibla direction. 
After the data is complete, then press calculate, the compass declination value will automatically appear, namely -0.33 . The next step is to determine the Earth's true North point using the formula developed by Tan's Compass Declination x 100, namely Tan 0.33 $\mathrm{x} 100=0.628326799$. To obtain an accurate calculation of the Qibla direction, the next step is to manually calculate the Qibla direction of the Muslim Muslimin Teladan Mosque.

Furthermore, the spherical triangle formula through the north point azimuth is used to calculate manually, namely:

$$
A Q=T a n \_1(1 /((1 / \tan B) x \sin A / \sin C-\cos A x(1 / \tan C))) \text {. }
$$

Where :

A score $=90$ - PE Muslimin Teladan Mosque (LU) is $90-3.601898=86.398102$.

B score $=90-\mathrm{PE} \mathrm{Ka'bah} \mathrm{(LU)} \mathrm{is} 90-21025$ ' 21,17” =68,58333334

$\mathrm{C}$ score $=$ Difference of Largest and Smallest Longitude $=$ LE Muslimin Teladan Mosque (BT) - LE Ka'bah (BT) is = 98.708031 - 390 49' $34,56 ”=58.8746977$

Thus each value can be entered using the formula "AQ = Tan-1 $(1 /$ ( $(1 /$ tan $68,58333334) \times \operatorname{Sin} 86.398102 / \operatorname{Sin} 58.8746977-\operatorname{Cos} 86.398102$ x ( $1 / \tan 58.8746977)$ ) ) The result is $\mathrm{AQ}=67.27491237=670$ 14' 57 ' from a North point to a West point. Whereas from the West point to the North point $90-67.27491237=22.72508763=220$ 43' 30". To determine the Qibla direction using a compass is $360-67.27491237=$ $292.7250876=2920$ 43' 30". While using the unit of centimeter it is determined by means of "Tan (90-AQ ) x 100" namely TAN (90-67.27491237) x $100=41.9 \mathrm{~cm}$ Information :

Tan $=$ Tangent

$\mathrm{AQ}=$ Qibla Direction

To apply these calculations in the field, several tools are needed including: A navigation compass to find out the four cardinal directions (East, West, North, South), one meter long ruler along with markers, right triangle, Water pass to find out the plane of the plane against the place where the qibla direction will be determined. The first step is to determine a flat place with a water pass then place the compass to find out the 4 cardinal directions, after knowing make a 1 meter long line between the south and north of the compass, then pull up from the North point of the compass of 0.6 as the true North point of the earth, draw an oblique line from the point south to true North of the earth, then draw a line from the point of the true West of the earth down to the middle point of the true North of the earth all the way to the point of the East. For the last, draw a line to the right from the true West of the earth at $41.9 \mathrm{~cm}$ then pull it down to form a rectangle towards the midpoint of the Earth's True North.

But in practice, you can also take advantage of the North of the compass by adding 0.628 points of true North of the earth with the Qibla direction of $41.9 \mathrm{~cm}$ to $0.628+41.9$ $=42.5 \mathrm{~cm}$. Thus using the compass North draw a line from the West of the compass to the right by $42.5 \mathrm{~cm}$, without redrawing the Earth's True North point. 


\section{Conclusion}

From the description and description that the author has described above, it can be seen that True North true north is any point on the earth to the North pole, this is because the North and South poles point precisely to the earth's axis of rotation. Therefore true north is North based on the earth's axis not North based on the earth's magnetism. So the difference is true North shows the true north direction of the earth while magnetic North is the North direction of the magnetic compass needle. Magnetic north does not coincide with Earth's true north.

To find out the true north of the earth can be done by using the formula: $\mathrm{AQ}=$ Tan-1 $(1 /((1 / \tan \mathrm{B}) \times \operatorname{Sin} \mathrm{A} / \operatorname{Sin} \mathrm{C}-\operatorname{Cos} \mathrm{A} \times(1 / \tan \mathrm{C})))$, after knowing the magnetic declination, you can use the formula Tan Compass Declination x 100 .

\section{References}

al-A'sqalâni, Ibnu Hajar. (2000). Fathu al-Barî bi Syarhi çahîh al-Bukarî. Berut : Darul Fikr.

Ali, M. Sayuti. (1997). Ilmu Falak. Jakarta : PT. Raja Grafindo Persada.

ARFA, Faisar Ananda. (2007). Filsafat hukum islam (Medan : Cita Pustaka.

Azhari, Susiknan. (2005). Esiklopedi Hisab Rukyah. Jogjakarta : Pustaka Pelajar.

al-Bantani, Nawawi. (2008). Nihâyah al-Zain. Berut : Darul Kutub Islamiah.

al-Bukhâri, Muhammad bin Ismail. (1987). çahîh al-Bukhâri. Berut : Daru ibnu Kafîr.

Fairu Zabadi, Majduddin Muhammad bin Ya'qub. (1987). Al-Qamus Al-Muhiith. Berut: Muassasah Risalah.

al-Ghazali, Abu Hamid Muhammad. (2007). al-Khulâjah. Berut : Daru al-Minhaj.

Harun, Tgk. H. M. Yusuf. (2008). Pengantar Ilmu Falak. Banda Aceh : Pena.

al-Jaziri, Abdurrahman. al-Figh A'la al-Mazahib al-Arba'ah. Berut : Darul Fikr, t.t.

Khazin, Muhyiddin. (2004). Ilmu Falak Dalam Teori Dan Praktek Perhitungan arah Kiblat, Waktu Shalat, Awal Bulan dan Gerhana. Yogyakarta : Buana Pustaka.

Muda, Tgk Mohd Ali. (1994). Rumus-Rumus Ilmu Falak Untuk Menetapkan Arah Kiblat dan Waktu Shalat. Diktat, IAIN-SU.

Muhajir, et al. (2019). Method of Parents in the Development of Child Prayers Attention Deficit Hyperactivity Disorder (ADHD)(Case Study of ADHD Children in Kulam Kemukiman Syamtarail Village, North Aceh). Britain International of Linguistics, Arts andEducation(BIoLAE)Journal, 278-290.

Tanjung, D. (2016). Keragaman penyimpangan akurasi arah kiblat Masjid-Masjid di Kota Medan (Tinjauan latar belakang, upaya Akurasi dan solusi) (Doctoral dissertation, Pascasarjana UIN Sumatera Utara), h. 36.

Yuslem, N. (2010). Kontekstualisasi Pemahaman Hadis. dalam MIQOT: Jurnal Ilmu-ilmu Keislaman, 34(1). 